\title{
Induction of Defense Reactions in Sugar Beet and Wheat by Treatment with Cell Wall Protein Fractions from the Mycoparasite Pythium oligandrum
}

\author{
Shigehito Takenaka, Zenta Nishio, and Yumi Nakamura
}

Department of Upland Agriculture, National Agricultural Research Center for Hokkaido Region, Shinsei, Memuro-cho, Kasaigun, Hokkaido 082-0071, Japan.

Accepted for publication 5 May 2003.

\begin{abstract}
Takenaka, S., Nishio, Z., and Nakamura, Y. 2003. Induction of defense reactions in sugar beet and wheat by treatment with cell wall protein fractions from the mycoparasite Pythium oligandrum. Phytopathology 93:1228-1232.

To detect molecules with elicitor properties from Pythium oligandrum, cell wall protein fractions (CWPs) were extracted from 10 P. oligandrum isolates and examined for elicitor activity in sugar beet and wheat. $P$. oligandrum isolates were divided into two groups based on the number of major proteins in CWP: isolates with two major proteins (D-type) and isolates with one major protein (S-type). Sugar beet seedlings treated with both types of CWP through their roots showed enhanced activities of phenylalanine ammonia lyase and chitinase, and D-type-treated seed-
\end{abstract}

ABSTRACT lings also showed significantly higher cell wall-bound phenolic compounds, mainly ferulic acid, compared with the distilled-water-treatment control. Damping-off severity was significantly reduced on seedlings treated with both types of CWP compared with the control, following challenge with Rhizoctonia solani AG2-2. Both types of CWP significantly reduced the number of infected spikelets developed from the injected spikelet compared with the control, following challenge with Fusarium graminearum. Neither type of CWP resulted in any reduction in pathogen growth rate in plate tests. These results demonstrate that CWPs of $P$. oligandrum have elicitor properties in sugar beet and wheat.

Additional keywords: Beta vulgaris, biocontrol mechanism, Fusarium head blight, Triticum aestivum.
Pythium oligandrum Drechs. has received considerable attention as a potential biocontrol agent of a number of soilborne plant pathogens. $P$. oligandrum has been reported to have an antagonistic activity via mycoparasitism $(5,6,15)$, antibiosis $(5,8,15)$, enzyme production (15), and competition for nutrients (17). $P$. oligandrum has been shown to colonize the rhizosphere of a wide range of agriculturally important crops (2). However, there is no direct evidence that $P$. oligandrum is plant pathogenic: Martin and Hancock (17) have shown that $P$. oligandrum was not pathogenic to 12 species of agriculturally important plants. Furthermore, recent investigations indicate additional advantages of this fungus as a biocontrol agent, including growth promotion of pepper (3). Light and electron microscope studies have shown that P. oligandrum penetrates the tomato root system without inducing extensive cell damage (23), and triggers an array of structural defenserelated reactions upon challenge with Fusarium oxysporum f. sp. radicis-lycopersici (4).

The induction of plant defense reactions is attractive because induced disease resistance is nonspecific in affording enhanced protection against different types of pathogens (32) and utilizes the plant's own defense mechanisms, which can be a natural, safe, effective, persistent, and durable alternative to pesticides in controlling plant diseases (31). It was anticipated that detecting molecules with elicitor properties from $P$. oligandrum would serve as a basis for further evaluation of its potential as a biocontrol agent of root pathogens. To date, a number of fungal elicitors have been isolated and characterized from the culture medium of fungi grown in vitro and from intercellular washing fluids of infected

Corresponding author: S. Takenaka; E-mail address: stake@affrc.go.jp

Publication no. P-2003-0728-05R

(C) 2003 The American Phytopathological Society plants. Among them, a family of small extracellular proteins produced by Phytophthora spp., called elicitins $(24,34)$, have been studied extensively for their biochemical and molecular characterizations and their biological activities (22). They have the interesting property of inducing necrosis and systemic acquired resistance on nonhost plants, including tobacco, and are readily translocated through the vascular system. Similar elicitin-like proteins have been detected from the culture filtrate of some Pythium spp. $(11,20)$. Recently, Picard et al. (21) purified a 10-kDa elicitin-like protein termed oligandrin from the culture filtrate of $P$. oligandrum. This protein displayed the ability to induce plant defense reactions upon challenge with Phytophthora parasitica in tomato plants. Protein and peptide elicitors have a potential application for controlling plant diseases via plant genetic transformation.

The most critical events underlying attachment and recognition between microorganisms and plants require cell surface molecules; therefore, the objective of this study was to detect the molecules with elicitor properties from the cell wall of P. oligandrum. Takenaka et al. $(29,30)$ already found that 13 Pythium spp., not including $P$. oligandrum, had species-specific proteins with distinctive and conserved structure in cell wall fragment, named alanine-rich hydroxyproline-containing wall proteins (AHWPs), whose biological functions have not been defined. Therefore, in this study, we attempted the extraction and the partial characterization of cell wall protein fractions (CWPs) from P. oligandrum isolates, which were distinct from oligandrin, and examined their ability to trigger induction of the defense reactions in sugar beet and wheat.

\section{MATERIALS AND METHODS}

Fungal cultures. Isolates of $P$. oligandrum used in this study are listed in Table 1. These isolates were grown in flasks con- 
taining $120 \mathrm{ml}$ of $10 \% \mathrm{~V}-8$ broth at $25^{\circ} \mathrm{C}$ for 3 weeks. Mycelial mats, collected by filtration, washed with distilled water, and blotted dry with a paper, were used for the extraction of CWPs.

For the production of inoculum of the sugar beet pathogen, Rhizoctonia solani AG2-2 isolate Pf-28 (isolated from sugar beet roots in Hokkaido prefecture; 18) was grown in flasks containing $25 \mathrm{~g}$ of vermiculite-wheat bran-Difco potato dextrose broth (PDB) medium ( $30 \mathrm{ml}$ of vermiculite, $30 \mathrm{ml}$ of wheat bran, $0.18 \mathrm{~g}$ of PDB, and $15 \mathrm{ml}$ of distilled water) at $25^{\circ} \mathrm{C}$ for 13 to 15 days. For the production of inoculum of the wheat pathogen, Fusarium graminearum isolate S1 (provided by Tokachi Agricultural Experiment Station, Japan) was cultured for 7 days on a potato dextrose agar medium, and conidia were produced in mung bean medium ( $20 \mathrm{~g}$ of mung beans in 1 liter of distilled water) through suspension culture.

Plant material. For the bioassay with sugar beet, sugar beet plants (cv. Megumi) were seeded in quartz sand in glass tubes and fertilized each days with $5 \mathrm{ml}$ of a nutrient solution as described by Abe (1). The plants (one plant/tube) were grown for 3 weeks in a growth chamber at $23^{\circ} \mathrm{C}$ with a 16 -h photoperiod. For the bioassay with wheat, Japanese spring wheat plants (cv. Harunoakebono) were cultivated in the greenhouse at 18 to $22^{\circ} \mathrm{C}$ with natural light until the flowering stage.

Electrophoretic analysis of CWPs. CWPs from nine isolates of $P$. oligandrum listed in Table 1 were extracted as described previously (29). The samples were fractionated by $12.5 \%$ sodium dodecyl sulfate-polyacrylamide gel electrophoresis (SDS-PAGE) in the discontinuous buffer system described by Laemmli (14), followed by Coomassie brilliant blue staining.

N-terminal amino acid sequence analysis. Major cell wall proteins from CWPs of $P$. oligandrum isolates MMR2 and MMR3 separated by SDS-PAGE were electroblotted onto polyvinylidene difluoride membranes (Immobilon-P ${ }^{\mathrm{SQ}}$; Millipore, Bedford, MA) as described by Hirano (10). Each blotted protein was sequenced by a gas-phase protein sequencer (Applied Biosystems, Foster, CA).

Enzyme assays. Three-week-old sugar beet seedlings grown under the above conditions were removed from the glass tubes and allowed to absorb $350 \mu \mathrm{l}$ of solutions containing $750 \mu \mathrm{g}$ of CWP of $P$. oligandrum isolates MMR2 or MMR3 through their root system. Control seedlings were treated with the same volume of distilled water (DW). The root and hypocotyl tissues from each of three seedlings collected at the indicated times after treatment were ground in liquid nitrogen. The resulting powder was suspended in $25 \mathrm{mM}$ sodium tetraborate buffer, $\mathrm{pH} 8.8$, containing $1 \%$ polyvinylpyrrolidone, $2 \mathrm{mM}$ ditihiothreitol (DTT) and $0.5 \mathrm{mM}$ phenylmethanesulphonylfluoride (PMSF) at $5 \mathrm{ml} / \mathrm{g}$ for phenylalanine ammonia-lyase (PAL) assay; and in $0.1 \mathrm{M}$ sodium citrate buffer, pH 5.0, containing $10 \%$ polyvinyl polypyrrolidone, $2 \mathrm{mM}$ DTT, and $0.5 \mathrm{mM} \mathrm{PMSF}$ at $4 \mathrm{ml} / \mathrm{g}$ for chitinase assay. The homogenate was centrifuged at $18,800 \times g$ for $20 \mathrm{~min}$ at $4^{\circ} \mathrm{C}$. Solid ammonium sulfate was added to the supernatant to $80 \%$ saturation and proteins were precipitated at $4^{\circ} \mathrm{C}$ for $60 \mathrm{~min}$. The pellet collected by centrifugation at $18,800 \times g$ for $60 \mathrm{~min}$ at $4^{\circ} \mathrm{C}$ was redissolved in $25 \mathrm{mM}$ sodium tetraborate buffer, $\mathrm{pH} 8.8$, $2 \mathrm{mM}$ DTT for PAL assay, and in $10 \mathrm{mM}$ sodium acetate buffer, $\mathrm{pH}$ 5.0, for chitinase assay to final volume of $2.5 \mathrm{ml}$. After desalting using Column PD-10 (Amersham Pharmacia Biotech $\mathrm{AB}$, Uppsala, Sweden), the protein fraction was used for enzyme assays. The protein content was determined by the method of Lowry et al. (16). PAL activity was determined using L-phenylalanine as substrate, by the method of Hugehes and Dickerson (12). Chitinase activity was determined using colloidal chitin as substrate, as described by Boller and Mauch (7). The experiment was conducted three times for each enzyme assay.

Quantification of cell wall-bound phenolics. Cell wall-bound phenolics were extracted from seedlings using a modified procedure described by Stadnik and Buchenauer (27). For this, $200 \mathrm{mg}$ of the root and hypocotyl tissues from each of three seedlings collected at the indicated times after CWP or DW treatment were ground in liquid nitrogen and extracted three times with $2 \mathrm{ml}$ of $80 \%$ methanol. The residue was suspended in $2 \mathrm{ml}$ of $0.5 \mathrm{M}$ $\mathrm{NaOH}$ and incubated on a shaker at room temperature for $16 \mathrm{~h}$ under nitrogen atmosphere. After centrifugation at $18,800 \times g$ for $20 \mathrm{~min}$, the supernatants were acidified to approximately $\mathrm{pH} 3$ with $\mathrm{HCl}$. The phenolic acids were extracted twice by addition of $1 \mathrm{ml}$ of ethyl acetate and evaporated to dryness. The resulting pellet was resolved in $1 \mathrm{ml}$ of methanol, and 1/10-diluted samples with DW were used for determination of phenolics and for highperformance liquid chromatography (HPLC) analysis. The determination of phenolics was performed by the method described by Swain and Hills (28). Phenolic content was determined using a standard curve prepared with $p$-coumaric acid. HPLC was carried out with a liquid chromatograph (Intelligent HPLC system; JASCO Co., Tokyo) equipped with a TSK-GEL ODS-80T (4.6 by $250 \mathrm{~mm}$, Tosoh Co., Tokyo), according to the method of Shibuya (25). Quantification was performed by external standard mode and ferulic and coumaric acids were injected as standard because these two phenolic acids are major wall-bound phenolic compounds in the case of wheat (27). The experiment was conducted four and three times for determination of phenolics and for HPLC analysis, respectively.

Sugar beet bioassay. After $12 \mathrm{~h}$ of absorption of CWP or DW as described above, each seedling was returned to quartz sand in a glass tube, inoculated by placing inoculum of $R$. solani ( $2 \mathrm{~g} / \mathrm{plant})$ around the root, and left in the growth chamber under the same condition for seedling growth. Disease severity of each treatment was estimated 14 days after inoculation as the index based on a 0 -to-5 scale where $0=$ no symptoms on hypocotyl, $1=$ necrosis of $<50 \%$ area of hypocotyl without constriction, $2=$ necrosis of $>50 \%$ area of hypocotyl without constriction or necrosis of $<50 \%$ area of hypocotyl with slight constriction, $3=$ necrosis of $>50 \%$ area of hypocotyl with slight constriction, $4=$ severe stunting of hypocotyl, and $5=$ seedling dead. Each treatment consisted of six plants and the experiment was conducted four times.

Wheat bioassay. At the anthesis day of wheat plants grown in the greenhouse under the conditions described above, each spike was treated with $10 \mu \mathrm{l}$ of solution containing $75 \mu \mathrm{g}$ of CWP from P. oligandrum isolates MMR2 or MMR3 or the same volume of DW by injection into a single spikelet located at the center of spike using a micropipette. The spike was detached $24 \mathrm{~h}$ after treatment, and $10 \mu \mathrm{l}$ of conidial suspension $\left(5 \times 10^{3}\right.$ conidia) of $F$. graminearum was injected into the same spikelet injected with CWP or DW. After inoculation, incubation continued at $22^{\circ} \mathrm{C}$ and $90 \%$ humidity with $10 \mathrm{~h}$ of daylight. Disease severity was scored with the number of infected spikelets developed around the injected spikelet 12 days after inoculation. Each treatment consisted of six plants (one spike/plant) and the experiment was conducted three times.

Statistical analysis. The effect of CWP on plant enzyme activities, plant cell wall-bound phenolic content, and disease suppression was determined by analysis of variance with treatment of experiments as blocks. The Dunnett's one-sided $t$ test was used to

TABLE 1. Isolates of Pythium oligandrum and their sources

\begin{tabular}{lll}
\hline Isolate number & Habitat & Origin \\
\hline MMR2 & Soybean soil & Memuro, Hokkaido prefecture \\
MMR3 & Wheat soil & Biei, Hokkaido prefecture \\
MMR7 & Wheat soil & Kunneppu, Hokkaido prefecture \\
MMR10 & Wheat soil & Memanbetsu, Hokkaido prefecture \\
MMR14 & Alfalfa soil & Kunneppu, Hokkaido prefecture \\
MMR15 & Timothy soil & Kunneppu, Hokkaido prefecture \\
MMR19 & Wheat soil & Kamikawa, Hokkaido prefecture \\
MMR21 & Wheat soil & Kamikawa, Hokkaido prefecture \\
IFO32559a & Vegetable soil & Sakai, Osaka prefecture \\
OPU425 & Vegetable soil & Sakai, Osaka prefecture \\
\hline
\end{tabular}

${ }^{\text {a }}$ Provided by M. Tojo, University of Osaka prefecture, Japan. 
determine significant differences between each type of CWP and the control $(P<0.05)$.

\section{RESULTS}

Partial characterization of CWP. When CWPs extracted from 10 isolates of $P$. oligandrum listed in Table 1 were applied to SDS-PAGE, two major proteins with molecular mass of $\approx 28 \mathrm{kDa}$ and $24 \mathrm{kDa}$ or one major protein of $\approx 27 \mathrm{kDa}$ were detected from these isolates (Fig. 1). That is, P. oligandrum isolates were divided into two classes based on the number of major protein. The CWPs, including two major proteins and only one major protein, were termed D-type and S-type of CWPs, respectively (Fig. 1D and S).

The N-terminal sequences of these three proteins from $P$. oligandrum isolates MMR2 (D-type) and MMR3 (S-type) were determined up to 20th amino acid residue (Fig. 2). The N-termini of the $28-\mathrm{kDa}$ protein of D-type and $27-\mathrm{kDa}$ protein of S-type were identical, and these two proteins and the $24-\mathrm{kDa}$ protein of D-type showed $65 \%$ sequence similarity. However, differences in the N-termini were observed between these three proteins and oligandrin described by Picard et al. (21).

Biological activity of CWP. PAL activity was measured in extracts of root and hypocotyl tissues from the CWP-treated and control sugar beet seedlings. Sugar beet seedlings treated with DW alone in the absence of CWP showed low PAL activity and no significant change throughout the assay (Fig. 3). In contrast, a rapid and transient increase in PAL activity was observed in seedlings treated with both types of CWP. Maximum activity was reached $4 \mathrm{~h}$ after treatment, and D-type and S-type caused

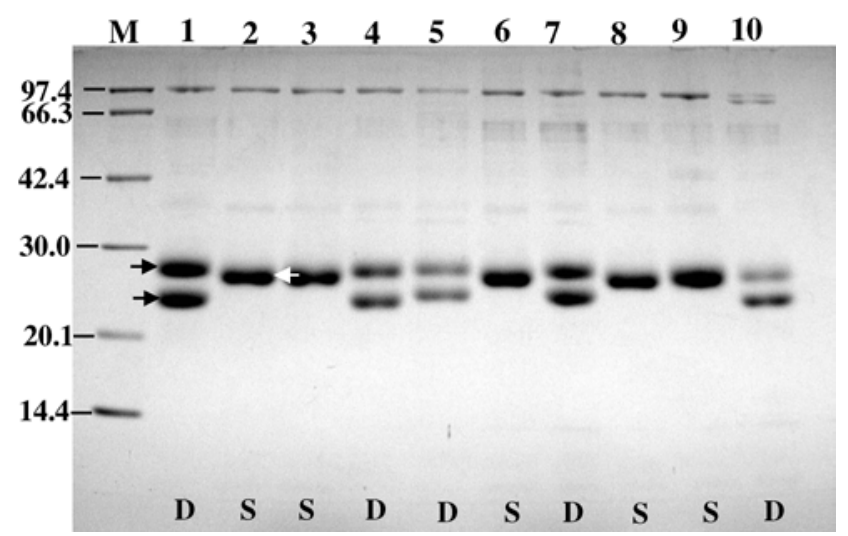

Fig. 1. Sodium dodecyl sulfate-polyacrylamide gel electrophoresis of cell wall protein fractions (CWPs) of 10 isolates of Pythium oligandrum. Each lane contained $4 \mu \mathrm{g}$ of protein and was stained with Coomassie brilliant blue. Arrows indicate major proteins, and D and S refer to D- and S-types of CWP, respectively. Lane M, molecular weight standards; lane 1, MMR2; lane 2, MMR3; lane 3, MMR7, lane 4, MMR10; lane 5, MMR14; lane 6, MMR15, lane 7, MMR19; lane 8, MMR21, lane 9, IFO32559; and lane 10, OPU425.

\section{8-kDa protein LTKEEXDAAFTGEVGKLTKD 27-kDa protein LTKEEXDAAFTGEVGKLTKD 24-kDa protein LTAKEXQDAFTGEVAKLTTG Oligand rin ATCTDEQFSDSIIKLTPAIG}

Fig. 2. The N-terminal amino acid sequence of three major proteins of cell wall protein fractions from Pythium oligandrum isolates MMR2 (D-type) and MMR3 (S-type). Standard one-letter amino acid code is used and X denotes an unidentified amino acid. Homologous amino acid residues are underlined among these three proteins. The N-terminal sequence of oligandrin was determined by Picard et al. (21). approximately 20- and 13-fold increase in PAL activity compared with DW treatment, respectively.

Next, accumulation of cell wall-bound phenolics was analyzed in the CWP-treated and control plants. The difference in content between D-type and DW was statistically significant $12 \mathrm{~h}$ after treatment (Fig. 4). HPLC analysis of the above phenolics indicated that the major component of cell wall-bound phenolics of sugar beet was ferulic acid; coumaric acid was not detected from any analyzed samples in sugar beet (Table 2). Similarly to the cell wall-bound phenolics $12 \mathrm{~h}$ after treatment, the content of ferulic acid in D-type treatment was significantly higher than that in DW treatment. However, the significant differences were not detected between the contents of S-type and DW.

Chitinase activity also was compared between the CWP-treated and control plants. Chitinase activity of DW-treated seedlings showed no significant change from 8 to $24 \mathrm{~h}$ after treatment (Fig. 5). A transient, but significant, increase in chitinase activity was found in the seedlings treated with D- and S-types of CWP $12 \mathrm{~h}$ after treatment (Fig. 5).

Disease suppression in sugar beet and wheat. To determine the ability of D- and T-types of CWP to induce resistance to $R$. solani in sugar beet, each type of CWP or DW-treated plants were

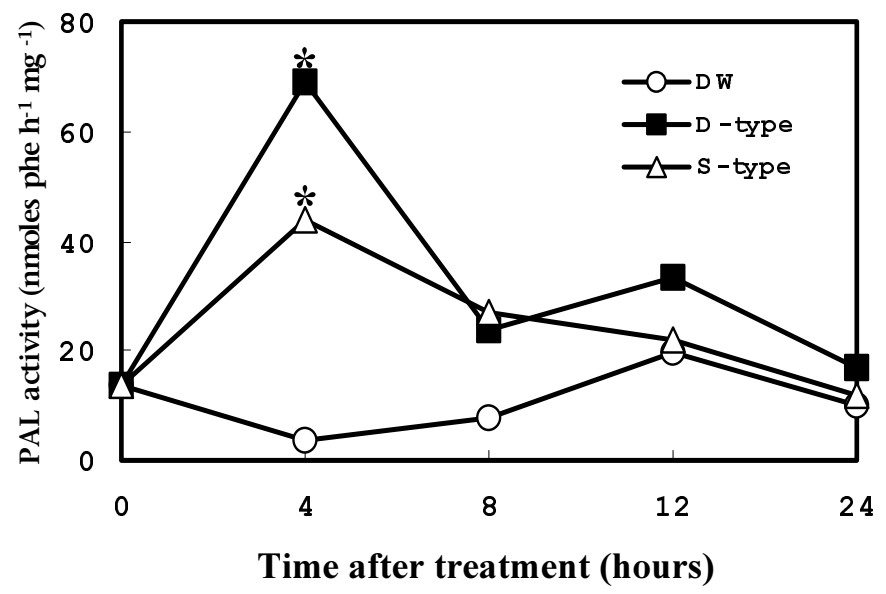

Fig. 3. Changes in phenylalanine ammonia-lyase (PAL) activity in root and hypocotyl tissues of sugar beet seedlings treated with distilled water (DW) or cell wall protein fractions from Pythium oligandrum isolates MMR2 (Dtype) or MMR3 (S-type). Values are the means of three independent experiments and asterisks indicate significant difference $(P<0.05)$ compared with DW treatment according to Dunnett's test.

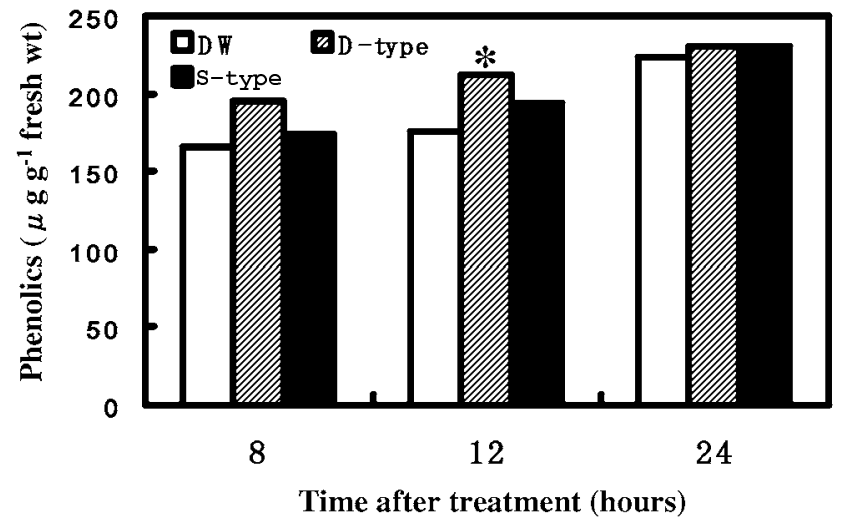

Fig. 4. Changes in cell wall-bound phenolics content in root and hypocotyl tissues of sugar beet seedlings treated with distilled water (DW) or cell wall protein fractions from Pythium oligandrum isolates MMR2 (D-type) or MMR3 (S-type). Values are the means of four independent experiments and an asterisk indicates significant difference $(P<0.05)$ compared with DW treatment according to Dunnett's test. 
challenged with $R$. solani $12 \mathrm{~h}$ after treatment. Disease severity 14 days after inoculation was significantly reduced by 32.6 and $35.5 \%$ on the treatments with D- type and S-type of CWP, respectively, when compared with the control (Table 3). When both types of CWP solution $(100 \mu \mathrm{g}$ in $50 \mu \mathrm{l})$ were applied to the paper disk located near the growing margin of fresh cultures of $R$. solani in plates, no reduction of fungal growth was observed (data not shown). These results demonstrate that CWPs do not act as antibiotics but act as elicitors in sugar beet.

Furthermore, wheat bioassay was conducted to determine whether CWPs also induce an effective defense response in wheat by injecting conidial suspension of $F$. graminearum into the same spikelet as was pre-injected with CWP or DW. As shown in Table 3 , both types of CWP significantly reduced the number of infected spikelets developed from the injected spikelet compared with DW treatment. CWPs also showed no effect on the growth of $F$. graminearum in plates (data not shown). These results suggested that CWPs also induce defense-related reactions in wheat to reduce the progression of Fusarium head blight in tissues.

\section{DISCUSSION}

Evidence is presented in this article that D- and S-types of CWP isolated from $P$. oligandrum display the ability to induce resistance in sugar beet against $R$. solani AG2-2, which is one of the pathogens of root rot and damping-off, and in wheat against $F$. graminearum, which is one of the pathogens of head blight. The finding that both types of CWP had no effect on the growth of $R$. solani and $F$. graminearum in plate tests indicates that CWP has no fungicidal activity against these two pathogens. Three major proteins of $\approx 28,27$, and $24 \mathrm{kDa}$ were detected from both types of CWP and they are distinct in molecular size from oligandrin reported by Picard et al. (21), which is a $10-\mathrm{kDa}$ protein purified from the culture filtrate of $P$. oligandrum and has the ability to induce resistance in tomato against Phytophthora parasitica. Furthermore, although the N-terminal amino acid sequence of these three cell wall proteins were similar up to the 20th residue, they are quite different from that of oligandrin reported by Picard et al. (21). Some Pythium spp. have been shown to have one or more species-specific cell wall proteins in the molecular mass range from $\approx 25$ to $40 \mathrm{kDa}(29,30)$. These species-specific cell wall proteins are known to have common epitope or epitopes and common characteristics of amino acid compositions; high content of alanine, and the presence of a significant amount of hydroxyproline. Takenaka and Kawasaki (29) named these cell wall proteins AHWPs. The above three major cell wall proteins of $P$. oligandrum strongly reacted with an antiserum against $P$. iwayamai AHWP (S. Takenaka and Y. Nakamura, unpublished data), suggesting that they belong to the AHWP family. Molecular and biochemical analyses of these three cell wall proteins of $P$. oligandrum are being pursued for their further characterization.

The effect of CWP treatments on the activity of PAL and the amount of cell wall-bound phenolic compounds in sugar beet seedlings were examined. PAL is the initial gateway enzyme in

TABLE 2. Composition of cell wall-bound phenolics obtained from root and hypocotyl tissues of sugar beet seedlings $12 \mathrm{~h}$ after treatment with distilled water (DW) or cell wall protein fractions (CWPs) from Pythium oligandrum isolates MMR2 (D-type) or MMR3 (S-type)

\begin{tabular}{lcc}
\hline Treatment & $\begin{array}{c}\text { Ferulic acid } \\
\left(\mu \mathrm{g} \mathrm{g}^{-1} \text { fresh wt }\right)\end{array}$ & $\begin{array}{c}\text { Coumaric acid } \\
\left(\mu \mathrm{g} \mathrm{g}^{-1} \text { fresh wt }\right)\end{array}$ \\
\hline DW & 82.9 & ND \\
D-type of CWP & $93.6^{*}$ & ND \\
S-type of CWP & 74.6 & ND \\
\hline
\end{tabular}

${ }^{a}$ Values are the means of three independent experiments and an asterisk indicates significant difference $(P<0.05)$ compared with DW treatment according to Dunnett's test. ND = not detected. phenolic compound biosynthesis; therefore, it is critical in determining the production rate of phenolic compounds (13). Previous studies strongly suggested that rapid esterification of phenolic compounds (cinnamic acids, in particular ferulic acid) into plant cell walls is a common and early response in the expression of resistance, resulting in cell strengthening (19). Furthermore, cinnamic acids such as ferulic and coumaric acids are known to be potentially toxic to pathogens (19). A recent study demonstrated the enhancement of PAL activity and accumulation of cell wallbound phenolic compounds (coumaric and ferulic acids) in wheat plants treated with benzo $(1,2,3)$ thiadiazole-7-carbothioic acid $S$ methyl ester (BTH), a novel systemic acquired resistance inducer, in response to powdery mildew infection (27). Similarly, in our study, rapid and transient increase in PAL activities was observed in CWP-treated sugar beet seedlings. Furthermore, sugar beet seedlings treated with D-type of CWP showed significantly higher content of cell wall-bound phenolic compounds than DW-treated seedlings. An ultrastructural and cytochemical study with tomato root tissues inoculated with $P$. oligandrum has shown that phenolic compounds may coat host walls and accumulate inside invaded cells (23). Although both coumaric and ferulic acids were detected in wheat plants as the wall-bound phenolic compounds (27), only ferulic acid was detected in sugar beet. These results suggest that wall-bound esterified ferulic acid may contribute to one of the defense reactions in sugar beet treated with CWP.

The chitinase activity in sugar beet seedlings following CWP treatments also was examined. Chitinase is induced by various factors, including pathogen and pest attack as well as treatment with elicitors, and has been shown to inhibit the growth of many

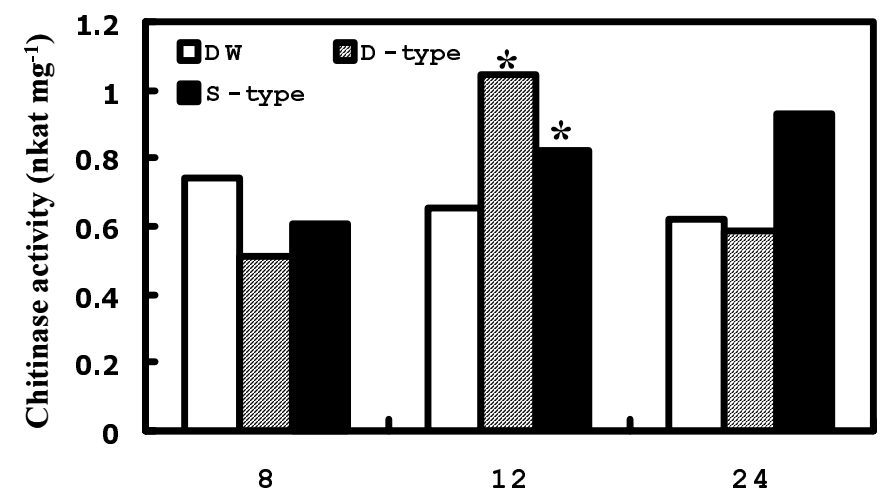

Time after treatment (hours)

Fig. 5. Changes in chitinase activity in root and hypocotyl tissues of sugar beet seedlings treated with distilled water (DW) or cell wall protein fractions from Pythium oligandrum isolates MMR2 (D-type) or MMR3 (S-type). Values are the means of three independent experiments and asterisks indicate significant difference $(P<0.05)$ compared with DW treatment according to Dunnett's test.

TABLE 3. Disease severities caused by Rhizoctonia solani AG2-2 in sugar beet seedlings and Fusarium graminearum in spikes of wheat treated with distilled water (DW) or cell wall protein fractions (CWPs) from Pythium oligandrum isolates MMR2 (D-type) and MMR3 (S-type) ${ }^{\mathrm{a}}$

\begin{tabular}{lcc}
\hline Treatment & $\begin{array}{c}\text { Disease severity index } \\
\text { of sugar beet }\end{array}$ & $\begin{array}{c}\text { Number of infected } \\
\text { spikelet of wheat }^{\mathrm{c}}\end{array}$ \\
\hline DW & 2.81 & 2.36 \\
D-type of CWP & $1.90^{*}$ & $1.72^{*}$ \\
S-type of CWP & $1.81^{*}$ & $1.54^{*}$ \\
\hline
\end{tabular}

a Values are the means of four (in sugar beet) and three (in wheat) independent experiments and asterisks indicate significant difference $(P<0.05)$ compared with DW treatment according to Dunnett's test.

${ }^{\mathrm{b}}$ Disease severity was estimated 14 days after inoculation.

${ }^{c}$ Disease severity was estimated 12 days after inoculation as the number of infected spikelets. 
fungi in vitro by causing lysis of hyphal tips, which has been considered one of the common plant defense mechanisms (9). In our study, significant but transient increase in chitinase activity was observed in sugar beet seedlings treated with CWP. Similarly, transient increases in chitinase activity also have been observed in cucumber and leek roots during the early stage of colonization by the biocontrol agent Trichoderma harzianum (33) and vesiculararbuscular mycorrhizae (26), respectively, both of whose ability to induce resistance has been suggested. These results suggest that transient increase in chitinase activity may be one of the expressions of defense reactions in plants activated by inducing agents.

Picard et al. (21) observed that oligandrin does not induce hypersensitive reaction-associated necrotic response when infiltrated into tomato leaves, which is a typical reaction in elicitintreated tobacco leaves. Their ultrastructural investigations showed higher electron density of the cell wall in oligandrin-treated tomato stem tissues followed by challenge with Phytophthora parasitica compared with nonoligandrin treated plants. Our CWP also did not induce root necrosis of sugar beet and increased the amount of host cell wall-bound phenolic compounds, indicating the possibility that the CWP described in this study and oligandrin trigger a similar host defense system. Further studies designed to examine the effect of CWP treatments on the accumulation of transcripts of genes associated with host defense are needed.

\section{ACKNOWLEDGMENTS}

This research was supported by a grant of "PIONEER research project" from the Ministry of Agriculture, Forestry and Fishery of Japan. We thank F. N. Martin, U.S. Department of Agriculture-Agricultural Research Service, for reviewing the manuscript; M. Tojo, University of Osaka prefecture, for providing P. oligandrum isolates; and M. Yamaguchi and $\mathrm{M}$. Iwamoto for their assistance with plant inoculations

\section{LITERATURE CITED}

1. Abe, H. 1987. Studies on the ecology and control of Polymyxa betae Keskin, as a fungal vector of the causal virus (beet necrotic yellow vein virus) of rhizomania disease of sugar beet. Hokkaido Cent. Agric. Exp. Stn. Rep. 60, Nagamura, Hokkaido, Japan.

2. Al-Rawahi, A. K., and Hancock, J. G. 1997. Rhizosphere competence of Pythium oligandrum. Phytopathology 87:951-959.

3. Al-Rawahi, A. K., and Hancock, J. G. 1998. Parasitism and biological control of Verticillium dahliae by Pythium oligandrum. Plant Dis. 82:1100-1106.

4. Benhamou, N., Rey, P., Cherif, M., Hockenhull, J., and Tirilly, Y. 1997. Treatment with mycoparasite Pythium oligandrum triggers induction of defense-related reactions in tomato roots when challenged with Fusarium oxysporum f. sp. radicis-lycopersici. Phytopathology 87:108-122.

5. Benhamou, N., Rey, P., Picard, K., and Tirilly, Y. 1999. Ultrastructural and cytochemical aspects of the interaction between the mycoparasite Pythium oligandrum and soilborne plant pathogens. Phytopathology 89:506-517.

6. Berry, L. A., Jones, E. E., and Deacon, J. W. 1993. Interaction of the mycoparasite Pythium oligandrum with other Pythium species. Biocontrol Sci. Technol. 3:247-260.

7. Boller, T., and Mauch, F. 1989. Colorimetric assay for chitinase. Methods Enzymol. 161:430-435.

8. Bradshaw-Smith, R. P., Whalley, W. M., and Craig, G. D. 1991. Interaction between Pythium oligandrum and the fungal footrot pathogens of peas. Mycol. Res. 95:861-865.

9. Collinge, D. B., Kragh, K. M., Mikkelsen, J. D., Nielsen, K. K., Rasmussen, U., and Vad, K. 1993. Plant chitinases. Plant J. 3:31-40.

10. Hirano, H. 1989. Microsequence analysis of winged bean seed proteins electroblotted from two-dimensional gel. J. Protein Chem. 8:115-130.

11. Huet, J. C., Le Care, J. P., Nespulous, C., and Pernollet, J. C. 1995. The relationships between the toxicity and the primary and secondary struc- tures of elicitin like protein elicitors secreted by the phytopathogenic fungus Pythium vexans. Mol. Plant-Microbe Interact. 8:302-310.

12. Hughes, R. K., and Dickerson, A. G. 1989. The effect of ethylene on phenylalanine ammonia lyase (PAL) induction by a fungal elicitor in Phaseolus vulgaris. Physiol. Mol. Plant Pathol. 34:361-378.

13. Jones, D. H. 1984. Phenylalanine ammonia-lyase: Regulation of its induction, and its role in plant development. Phytochemistry 23:1349-1360.

14. Laemmli, U. K. 1970. Cleavage of structural proteins during the assembly of the head of bacteriophage T4. Nature (Lond.) 227:680-685.

15. Lewis, K., Whipps, J. M., and Cooke, R. C. 1989. Mechanisms of biological disease control with special reference to the case study of Pythium oligandrum as an antagonist. Pages 191-217 in: Biotechnology of Fungi for Improving Plant Growth. J. M. Whipps and R. D. Lumdsen, eds. Cambridge University Press, Cambridge.

16. Lowry, O. H., Rosebrough, N. J., Farr, A. L., and Randall, R. J. 1951. Protein measurement with the Folin phenol reagent. J. Biol. Chem. 193:265-275.

17. Martin, F. N., and Hancock, J. G. 1987. The use of Pythium oligandrum for biological control of preemergence damping-off caused by $P$. ultimum. Phytopathology 77:1013-1020.

18. Naito, S., Yamaguchi, T., and Sugimoto, T. 1974. Grouping of isolates of Rhizoctonia solani Kuhn from root rot of sugar beets. Res. Bull. Hokkaido Natl. Agric. Exp. Stn. 108:45-53.

19. Nicholson, R. L., and Hammerschmidt, R. 1992. Phenolic compounds and their role in disease resistance. Annu. Rev. Phytopathol. 30:369-389.

20. Panabières, F., Ponchet, M., Allasia, V., Cardin, L., and Ricci, P. 1997. Characterization of border species among Pythiaceae: Several Pythium isolates produce elicitins, typical proteins from Phytophthora spp. Mycol. Res. 101:1450-1468.

21. Picard, K., Ponchet, M., Blein, J. P., Rey, P., Tirilly, Y., and Benhamou, N. 2000. Oligandrin. A proteinaceous molecule produced by the mycoparasite Pythium oligandrum induces resistance to Phytophthora parasitica infection in tomato plants. Plant Physiol. 124:379-395.

22. Ponchet, M., Panabières, F., Milat, M.-L., Mikes, V., Montillet, J.-L., Suty, L., Triantaphylides, C., Tirilly, Y., and Blein, J.-P. 1999. Are elicitins cryptograms in plant-Oomycete communications? CMLS, Cell. Mol. Life Sci. 56:1020-1047.

23. Rey, P., Benhamou, N., Wulff, E., and Tirilly, Y. 1998. Interactions between tomato (Lycopersicon esculentum) root tissues and the mycoparasite Pythium oligandrum. Physiol. Mol. Plant Pathol. 53:105-122.

24. Ricci, P. 1997. Induction of the hypersensitive response and systemic acquired resistance by fungal proteins: The case of elicitins. Pages 53-75 in: Plant-Microbe Interactions, vol. 3. G. Stacey and N. T. Keen, eds. The American Phytopathological Society, St. Paul, MN.

25. Shibuya, N. 1984. Phenolics acids and their carbohydrate esters in rice endosperm cell walls. Phytochemistry 23:2233-2237.

26. Spanu, P., Boller, T., Ludwig, A., Weimken, A., Faccio, A., and Bonfante-Fasolo, P. 1989. Chitinase in roots of mycorrhizal Allium porrum: Regulation and localization. Planta 177:447-455.

27. Stadnik, M. J., and Buchenauer, H. 2000. Inhibition of phenylalanine ammonia-lyase suppresses the resistance induced by benzothiadiazole in wheat to Blumeria graminis f. sp. tritici. Physiol. Mol. Plant Pathol. 57:25-34.

28. Swain, T., and Hilli, W. E. 1959. The phenolic constituents of Prunus domestica. J. Soil Food Agric. 10:63-68.

29. Takenaka, S., and Kawasaki, S. 1994. Characterization of alanine-rich, hydroxyproline-containing cell wall proteins and their application for identifying Pythium species. Physiol. Mol. Plant Pathol. 45:249-261.

30. Takenaka, S., Tojo, M., Kawasaki, S., and Ichitani, T. 1994. Characterization of cell wall proteins in several species of Pythium. (Abstr.) Phytopathology 84:1098.

31. Tuzun, S., and Kloepper, J. W. 1995. Practical application and implementation of induced resistance. Pages 152-168 in: Induced Resistance to Disease in Plants. R. Hammerschmidt and J. Kuc, eds. Kluwer Academic Publishers, Dordrecht, the Netherlands.

32. Van Loon, L. C. 1997. Induced resistance in plants and the role of pathogenesis-related proteins. Eur. J. Plant Pathol. 103:753-765.

33. Yedidia, I., Benhamou, N., and Chet, I. 1999. Induction of defense response in cucumber plants (Cucumis sativus L.) by the biocontrol agent Trichoderma harzianum. Appl. Environ. Microbiol. 65:1061-1070.

34. Yu, L. M. 1995. Elicitins from Phytophthora and basic resistance in tobacco. Proc. Natl. Acad. Sci. USA 92:4088-4094. 